\title{
The Relationship between the Distribution of Invasive Plant Alternanthera philoxeroides and Soil Properties is Scale-Dependent
}

\author{
Xiaocui Chen ${ }^{1}$, Renqing Wang ${ }^{1,2,3}$, Qingqing Cao', \\ Haijie Zhang, Xiuli Ge ${ }^{4}$, Jian Liu ${ }^{1 *}$ \\ 'Institute of Environmental Research, Shandong University, Jinan 250100, China \\ ${ }^{2}$ School of Life Science, Shandong University, Jinan 250100, China \\ ${ }^{3}$ Shandong Provincial Engineering and Technology Research Center for Vegetation Ecology, \\ Shandong University, Jinan 250100, China \\ ${ }^{4}$ School of Environmental Science and Engineering, Qilu University of Technology, Jinan 250353, China
}

Received: March 30, 2015

Accepted: May 25, 2015

\begin{abstract}
Understanding the relationship between invasive plants and soil properties improves our ability to predict potential areas that could be invaded. To explore spatial scaling effects on the distribution of the invasive plant Alternanthera philoxeroides, we conducted field research at six rivers (three rivers were lightly invaded and the other three were heavily invaded by $A$. philoxeroides) near Nansi Lake, China, and compared characteristics of pairs of plots ( $4 \mathrm{~m}^{2}$ in area) with and without $A$. philoxeroides on two scales. For each plot we measured plant-related parameters, including plant coverage; biomass; the carbon-to-nitrogen ratio in root, stem, and leaf; and soil-related parameters, including soil $\mathrm{pH}$ value, soil moisture, soil organic carbon (SOC), and soil total nitrogen (TN). At the river scale, rivers with higher SOC and soil TN had higher A. philoxeroides coverage. However, at the plot scale there was no significant difference in the soil properties of paired plots with and without $A$. philoxeroides. Only the root carbon-to-nitrogen ratio was correlated significantly with soil properties at the river scale, suggesting that roots played a vital role in the response to changeable soil conditions. Soil $\mathrm{pH}$ was negatively correlated with weed coverage, SOC, and soil TN. Invasive plant distribution may be positively related to SOC and soil TN of rivers, and efforts to prevent an A. philoxeroides invasion should focus on rivers with higher SOC and soil TN and lower soil $\mathrm{pH}$.
\end{abstract}

Keywords: Alternanthera philoxeroides, invasive species, Nansi Lake, soil organic carbon, soil total nitrogen

\section{Introduction}

Biological invasion is a global environmental problem that poses a serious threat to native ecosystems $[1,2]$. Numerous studies have documented the effects of invasive plants to alter biodiversity [3], hydrology [4], nutri-

*e-mail: ecology@sdu.edu.cn ent cycling [5], fire frequency [6], soil properties, and disturbance regimes, as well as affecting many aboveand below-ground trophic interactions [7]. The impacts of plant invasion on soil nutrient dynamics include carbon acquisition, an elevation in total carbon and nitrogen content, and changes to soil moisture $[8,9]$. The impacts of invasive species range from the local to the global scales. 
What makes an environment susceptible to invasion and what enables a species to invade successfully are the two central questions of biological invasion [10, 11]. Exploring the relationship between invasive species and environmental factors will help to elucidate invasion mechanisms. Human disturbance, temperature, latitude, soil properties, soil microorganisms, and various environmental factors may be associated with biological invasion [12-16]. Latitude strongly affects the distribution pattern of invasive plants in China at the provincial scale [17]. However, different factors play a decisive role at different scales. Abiotic processes are much more important determinants of invasion success than biotic processes at large spatial scales, while the opposite is true at small spatial scales [7, 18-20]. For example, the highest annual temperature was significantly correlated with the index of invasion at the regional scale, but the factors were not correlated at the provincial scale [21].

Wetlands, one of the world's most important ecosystems, are valued for their ability to store floodwater, purify water, and provide habitat for waterfowl and other wildlife [22]. Soil organic matter of wetlands directly affects the production ability of these ecosystems and is the most important source of nutrients for wetland plants. Nitrogen, phosphorus, and potassium are the main limiting nutrients in wetland soil and are also the main essential elements for plant growth and development. The amounts of soil nitrogen, soil phosphorus, and soil potassium directly affect plant growth, as well as ecosystem stability and material circulation balance [23]. Therefore, studying the relationship between plants' distribution and soil properties has significant theoretical value and practical implications.

The invasive plant alligator weed Alternanthera philoxeroides (Mart.) Griseb., is found throughout Nansi Lake, China, where it produces dense mats that disrupt the ecology of the riparian area, stream banks, and shallow water. It spreads its propagules through hydrochory [24] and uses dispersal by fragmentation, a technique that is par- ticularly effective for aquatic plants [25]. A. philoxeroides prefer the fertile and moist environment at the junction of the land and water in freshwater ecosystems in warm temperate and tropical zones [26].

Although numerous studies have documented the relationship between plant invasion and soil properties [5, 15, 27-29], little attention has been paid to understanding how soil properties affect the distribution of $A$. philoxeroides and whether such abiotic factors are scale-dependent. The aim of our work was to explore the environmental factors that influence the distribution of $A$. philoxeroides in the main rivers around Nansi Lake at two different scales (river scale and plot scale). After conducting preliminary surveys of A. philoxeroides distribution on rivers flowing into Nansi Lake in summer 2012 and 2013, we conducted the field investigations of the relationship between $A$. philoxeroides and environmental factors in June 2014. We explored the following questions:

1) How do nutrient properties in riparian soil, such as soil total nitrogen (TN) and soil organic carbon (SOC), affect the distribution of $A$. philoxeroides?

2) Do the factors affecting the distribution of $A$. philoxeroides differ at the river and plot scales?

\section{Methods}

\section{Study Area and Species}

The study was conducted in Nansi Lake (34 $27^{\prime}$ $35^{\circ} 20^{\prime} \mathrm{N}$, and $116^{\circ} 34^{\prime}-117^{\circ} 21^{\prime} \mathrm{E}$ ), located in southwest Shandong Province and encompassing Nanyang Lake, Dushan Lake, Zhaoyang Lake, and Weishan Lake. The total area is $1,266 \mathrm{~km}^{2}$, the drainage area is more than 31,700 $\mathrm{km}^{2}$, and the mean depth is $1.5 \mathrm{~m}$. It is classified as a large shallow lake. The lake has a temperate continental monsoon climate with $870 \mathrm{~mm}$ of annual average rainfall and an annual average temperature of $13.6^{\circ} \mathrm{C}$.

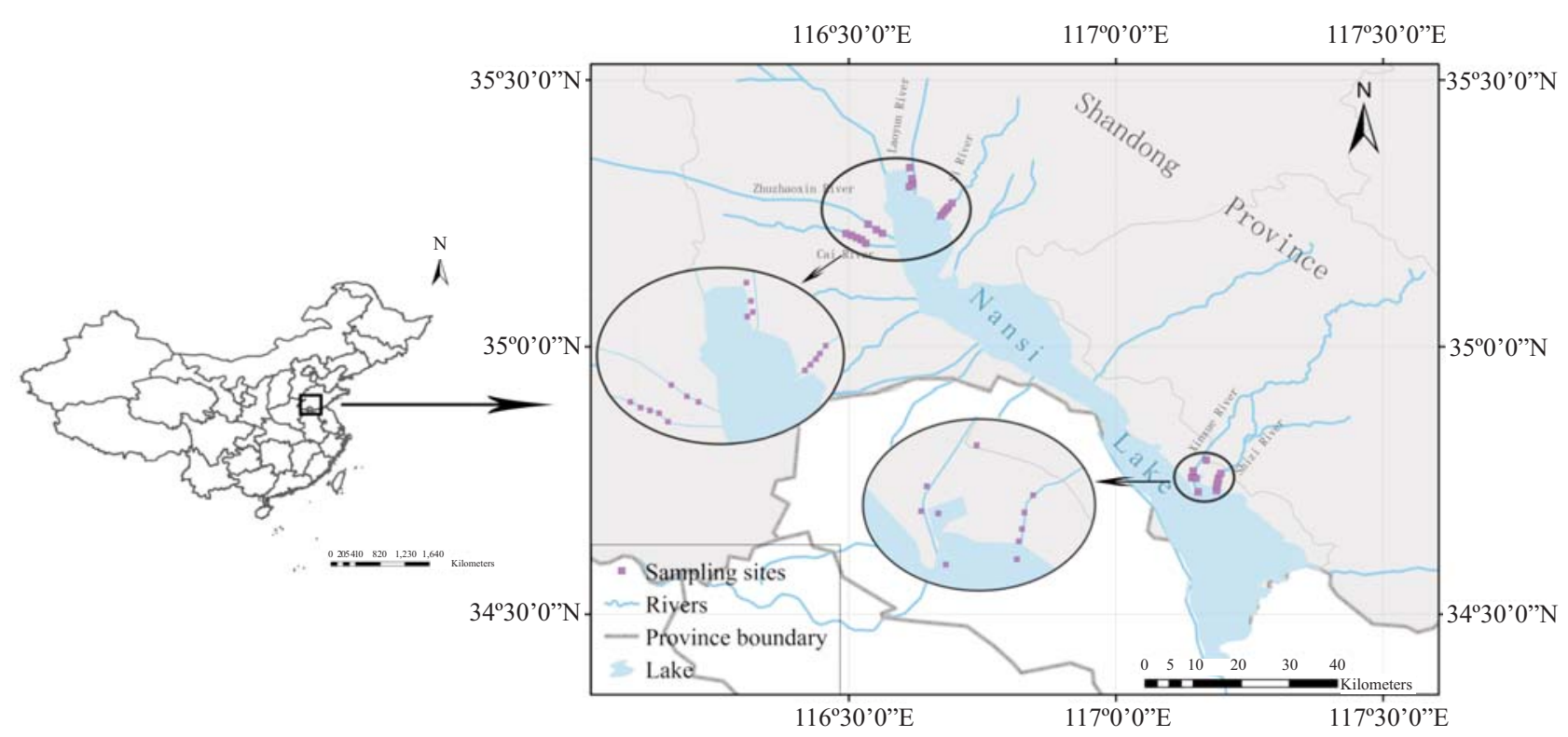

Fig. 1. Distribution of study sites around Nansi Lake. 
Table 1. Basic information about the six researched rivers.

\begin{tabular}{|l|c|c|}
\hline \multicolumn{1}{|c|}{ River } & Length $(\mathrm{km})$ & Basin area $\left(\mathrm{km}^{2}\right)$ \\
\hline Cai River & 36 & 322 \\
\hline Laoyun River & 5.9 & 30 \\
\hline Shizi River & 22 & 296 \\
\hline Si River & 159 & 2,366 \\
\hline Xinxue River & 22 & 663 \\
\hline Zhuzhaoxin River & 141 & 4,206 \\
\hline
\end{tabular}

Nansi Lake is fed by 53 main rivers, not all of which are suitable for research purposes (e.g. some rivers are shipping lanes where A. philoxeroides cannot form monocoenosis on the water surface). According to our pilot studies, the infestations in Xinxue River, Shizi River, and Laoyun River were particularly serious, with vegetation sometimes expanding 2-4 $\mathrm{m}$ from the riverbank and continuing for 100 $\mathrm{m}$ along the river. In other lightly infested areas, such as Baima River and Si River, the weed was only distributed in small patches. We chose six rivers (Xinxue River, Shizi River, Laoyun River, and Si River - all studied in 2012 and 2013, as well as the Cai River and Zhuzhaoxin River, both studied in 2014) and further examined the relationship between A. philoxeroides and soil properties of the rivers in June 2014 (Fig. 1, Table 1). A. philoxeroides was relatively rare in the Si River, Cai River, and Zhuzhaoxin River.

A. philoxeroides, a member of the Amaranthaceae family, is an aggressive, stoloniferous, perennial rhizomatous herb that grows rapidly in habitats ranging from dry terrestrial to aquatic. It originated in the Parana River alluvial plain in northern Argentina but has spread to many parts of the world and is considered a serious invasive species in the United States, Australia, New Zealand, Thailand, and China. A. philoxeroides was first introduced to China as animal feed in the 1930s and then spread rapidly throughout most provinces. The stems of $A$. philoxeroides are hollow, buoyant, and easily broken, which contribute to its dispersal ability and invasiveness in aquatic environments. In aquatic systems, $A$. philoxeroides typically emerges from below-ground buds (on storage roots) in spring and then spreads rapidly throughout the growing season, forming a dense free-floating mat of vegetation on the water surface [30]. It overwinters with storage roots and rhizomes [31]. Invasion is serious in areas in which the average temperature in January is $2-4^{\circ} \mathrm{C}$. The weed occurs in regions from $100^{\circ}-121^{\circ} \mathrm{E}$ and $18^{\circ}-38^{\circ} \mathrm{N}$, and covers 22 provinces in China [14]. The habitat of $A$. philoxeroides in our survey was aquatic.

\section{Field Sampling}

We applied a paired-plot sampling design, choosing two plots at each location: one with $A$. philoxeroides cover and the other without. Each plot pair was chosen so that: (i) the plots were at least $5 \mathrm{~m}$ apart,

(ii) each plot was about $2 \mathrm{~m} \times 2 \mathrm{~m}$, with an area of at least $4 \mathrm{~m}^{2}$,

(iii) the bar surface at both plots was at the same elevation, in order to control for flooding frequency and vertical distance to the water table or capillary fringe (the driving factors in plant water availability).

We sampled soil at 24 plots with $A$. philoxeroides and another 27 similar plots without $A$. philoxeroides (including three plots in Zhuzhaoxin River, where no A. philoxeroides was distributed). Plots without weed were all adjacent to plots with weed, allowing comparative analysis, except in the case of two plots that were invaded to such an extent that there were no nearby weed-free plots. Soil samples were collected using a customised stainless steel sampler. In each study plot, we randomly collected three cores to form a mixed sample. The position of survey points was determined by GPS, and plots were recorded in digital photos.

After measuring the coverage of A. philoxeroides at each plot, we randomly selected four or five main stem branches of weed that were as long and intact as possible for laboratory analysis.

Soil samples were analyzed for soil moisture, soil $\mathrm{pH}$, total soil carbon (TC), total soil nitrogen (TN), and soil organic carbon (SOC), while samples of roots, stems, and leaves were analyzed for biomass, TC, and TN.

\section{Laboratory Analysis}

After obvious plant material was removed from the soil samples with forceps, the samples were air-dried. Basic soil properties were identified following the standard methods recommended by the Chinese Society of Soil Science [32]. A sub-sample of each soil sample was dried at $105^{\circ} \mathrm{C}$ for 24 hours to determine the soil moisture content. Soil $\mathrm{pH}$ was determined with a PHS-3C pH meter in a 1:2.5 suspension in $\mathrm{H}_{2} \mathrm{O}$. Soil organic matter was determined by oxidation with a potassium dichromate-titration of $\mathrm{FeSO}_{4}$ [32].

Collected plant samples were carefully washed and then separated into root, stem, and leaf samples with tweezers. Plant samples of roots, stems, and leaves were dried at $65^{\circ} \mathrm{C}$ to constant weight and then ground to pass through a 20 mesh sieve. The different types of samples were weighed using an electronic scale. The TC and TN of soil and plants were analyzed using an Elementar Analysensysteme (Vario EL III, Germany) in order to calculate the carbon-to-nitrogen $(\mathrm{C} / \mathrm{N})$ ratio in the soil and in the roots, stems, and leaves.

\section{Statistical Analysis}

All data were analyzed using SPSS (version 21.0). Oneway ANOVA was used to determine the significant differences in physical properties between different rivers, and Pearson correlation was performed to compare environmental factors and plant properties. Bar charts and box charts were created by SigmaPlot (version 12.5) and Adobe Photoshop CS6. 
Table 2. Correlation analysis between plant and soil properties of plots invaded by Alternanthera philoxeroides.

\begin{tabular}{|l|c|c|c|c|c|c|c|c|c|c|c|}
\hline $\begin{array}{c}\text { Pearson } \\
\text { correlation }\end{array}$ & Coverage & $\begin{array}{c}\text { Total } \\
\text { biomass }\end{array}$ & $\begin{array}{c}\text { Root/ } \\
\text { shoot }\end{array}$ & $\begin{array}{c}\text { Root } \\
\text { C/N }\end{array}$ & $\begin{array}{c}\text { Stem } \\
\text { C/N }\end{array}$ & $\begin{array}{c}\text { Leaf } \\
\text { C/N }\end{array}$ & Soil TN & Soil TC & Soil pH & $\begin{array}{c}\text { Soil } \\
\text { moisture }\end{array}$ & SOC \\
\hline Coverage & 1 & & & & & & & & & & \\
\hline Total biomass & $0.744^{* *}$ & 1 & & & & & & & & & \\
\hline Root/shoot & -0.208 & -0.389 & 1 & & & & & & & & \\
\hline Root C/N & $-0.569^{* *}$ & -0.372 & $0.675^{* *}$ & 1 & & & & & & & \\
\hline Stem C/N & -0.015 & 0.099 & 0.149 & 0.081 & 1 & & & & & & \\
\hline Leaf C/N & -0.267 & -0.082 & 0.435 & 0.435 & $0.826^{* *}$ & 1 & & & & & \\
\hline Soil TN & 0.323 & $0.468^{*}$ & -0.429 & -0.429 & 0.077 & -0.163 & 1 & & & & \\
\hline Soil TC & 0.061 & 0.060 & -0.287 & -0.287 & -0.014 & -0.219 & $0.689^{* *}$ & 1 & & & \\
\hline Soil pH & $-0.602^{* *}$ & -0.358 & $0.539^{*}$ & $0.539^{*}$ & 0.065 & 0.3 & $-0.755^{* *}$ & $-0.472^{*}$ & 1 & & \\
\hline Soil moisture & 0.222 & 0.052 & -0.139 & $-0.491^{*}$ & 0.078 & -0.21 & $0.675^{* *}$ & $0.837^{* *}$ & $-0.630^{* *}$ & 1 & \\
\hline SOC & 0.163 & 0.239 & -0.235 & -0.395 & 0.067 & -0.16 & $0.898^{* *}$ & $0.874^{* *}$ & $-0.648^{* *}$ & $0.819^{* *}$ & 1 \\
\hline Mean SOC & $0.575^{* *}$ & $0.488^{*}$ & -0.362 & $-0.639^{* *}$ & 0.131 & -0.165 & $0.704^{* *}$ & $0.519^{*}$ & $-0.683^{* *}$ & $0.543^{*}$ & $0.687^{* *}$ \\
\hline
\end{tabular}

${ }^{1} \mathrm{C} / \mathrm{N}$ - carbon-to-nitrogen ratio; $\mathrm{TN}$ - total nitrogen; TC - total carbon; SOC - soil organic carbon

${ }^{*}$ Correlation is significant at the 0.05 level (2-tailed). ${ }^{* *}$ Correlation is significant at the 0.01 level (2-tailed). Mean SOC is average level of SOC of river.

\section{Results}

\section{General Distribution of A. philoxeroides in Nansi Lake}

Our investigation revealed that the river-wide coverage of $A$. philoxeroides was as much as $30 \%$ in the Xinxue, Shizi, and Laoyun rivers, and mean coverage of weed was over $80 \%$ at these sites. In contrast, mean coverage was just $5 \%$ in the $\mathrm{Si}$ and Cai rivers. No A. philoxeroides was found

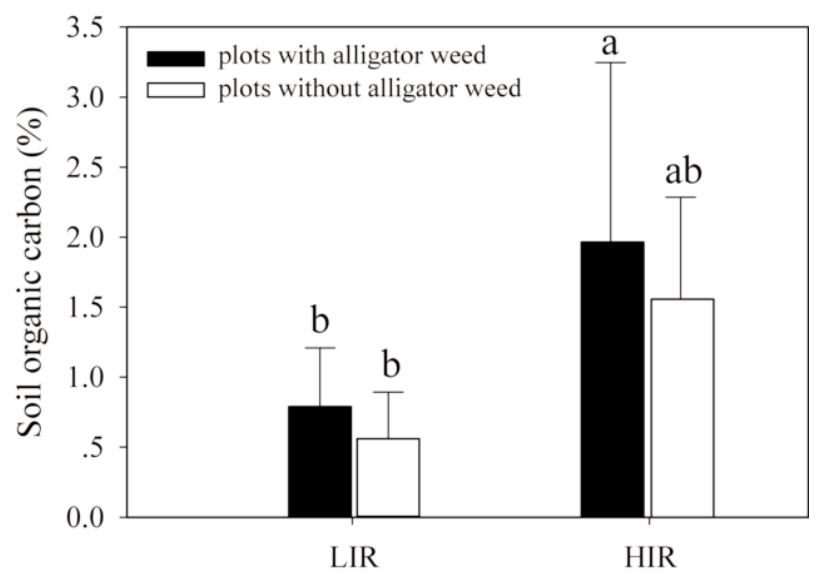

Fig. 2. Soil organic carbon in rivers affected by the invasive weed Alternanthera philoxeroides, including lightly invaded rivers (LIR; $\mathrm{n}=8$ for both plots) and heavily invaded rivers (HIR; $\mathrm{n}=12$ for both plots). The means ( \pm standard deviation) are presented for all the data. Different lowercase letters indicate significant differences between lightly invaded and highly invaded rivers (one-way ANOVA analysis, KolmogorovSmirnov test, $\mathrm{p}<0.05)$. in the Zhuzhaoxin River. Therefore, the Xinxue, Shizi, and Laoyun were considered heavily invaded rivers, and the $\mathrm{Si}$ and Cai were considered lightly invaded rivers. The Zhuzhaoxin River was eliminated from further analysis.

The average SOC was higher in heavily invaded rivers than lightly invaded rivers, but there was no significant difference between invaded and non-invaded plots between the two types of rivers (Fig. 2).

The median root $\mathrm{C} / \mathrm{N}$ ratio was much higher in lightly invaded rivers than heavily invaded rivers, and the range of root $\mathrm{C} / \mathrm{N}$ was narrow in heavily invaded rivers (Fig. 3A). Meanwhile, stem and leaf $\mathrm{C} / \mathrm{N}$ did not differ from one another noticeably in the two types of rivers (Figs. 3B and C). The average soil $\mathrm{pH}$ (Fig. 3E) was slightly more alkaline, and soil TN (Fig. 3D) and soil moisture (Fig. 3F) were lower in lightly invaded rivers than in heavily invaded ones.

\section{Correlations between Plant Distribution and Soil Properties in Plots}

Correlation analysis among the parameters of invaded plots revealed that weed coverage was significantly correlated with plant root $\mathrm{C} / \mathrm{N}$ ratio, soil $\mathrm{pH}$, mean $\mathrm{SOC}$, and soil moisture. Biomass was significantly positively correlated with soil TN and mean SOC. The root-to-shoot ratio showed a strong positive correlation with soil $\mathrm{pH}$ and the plant root $\mathrm{C} / \mathrm{N}$ ratio. The plant root $\mathrm{C} / \mathrm{N}$ ratio was not significantly correlated with $\mathrm{SOC}$ at the plot scale, but it was obviously negatively correlated with $\mathrm{SOC}$ at the river scale and positively correlated with soil $\mathrm{pH}$ at the plot scale (Table 2).

According to one-way ANOVA analysis, soil TN, soil $\mathrm{TC}$, soil $\mathrm{C} / \mathrm{N}$ ratio, and SOC significantly differed among the five investigated rivers $(\mathrm{p}<0.001)$. Significant differ- 
ences were found in the plant root $\mathrm{C} / \mathrm{N}$ ratio, soil moisture, and soil $\mathrm{pH}$ value $(\mathrm{p}<0.05)$ (Table 3$)$. Rivers with high weed coverage, such as the Laoyun and Xinxue, had lower plant root $\mathrm{C} / \mathrm{N}$ ratios than did rivers with low weed coverage.

\section{Discussion}

The distribution pattern of $A$. philoxeroides was spatially heterogeneous in different rivers. Much of this discrepancy was correlated with soil properties, such as mean SOC, soil moisture, and soil TN. Soil moisture is a vital fac-
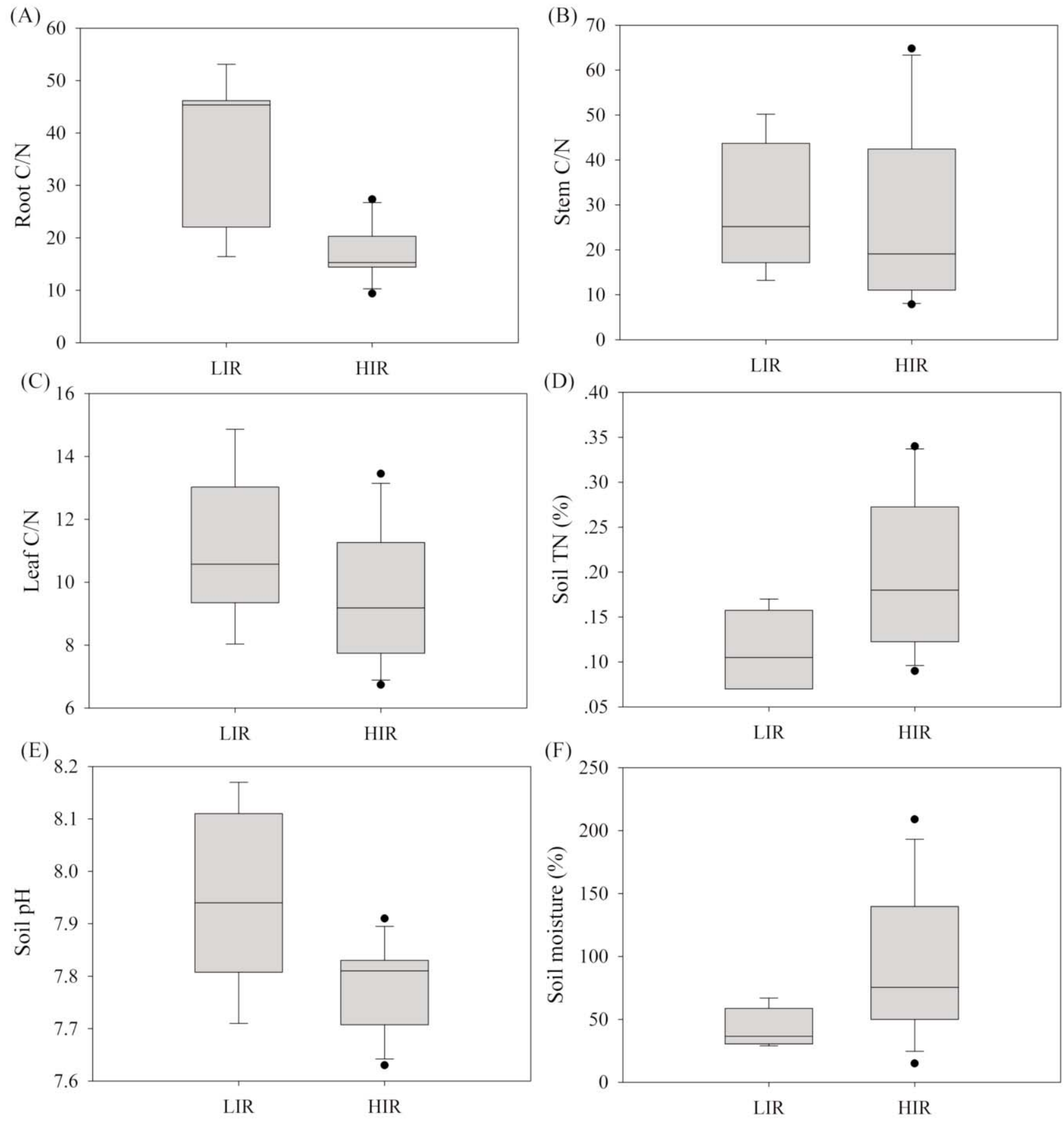

tor affecting carbon and nitrogen dynamics [5]. It also affects nitrification, along with soil $\mathrm{pH}$, soil aeration, and soil temperature. Our study revealed that soil $\mathrm{pH}$ was negatively correlated with SOC and soil TN, concurring with previously reported results [33]. In our study, soil $\mathrm{pH}$ was also negatively correlated with weed coverage and soil TN, indicating that $A$. philoxeroides prefers soil with lower $\mathrm{pH}$ (to a certain degree). Our results indicated that lower soil $\mathrm{pH}$ can raise soil TN, soil TC, and SOC, which promotes A. philoxeroides growth in the lake we evaluated.

The correlation analysis revealed that the coverage of A. philoxeroide was more closely related to root $\mathrm{C} / \mathrm{N}$ than

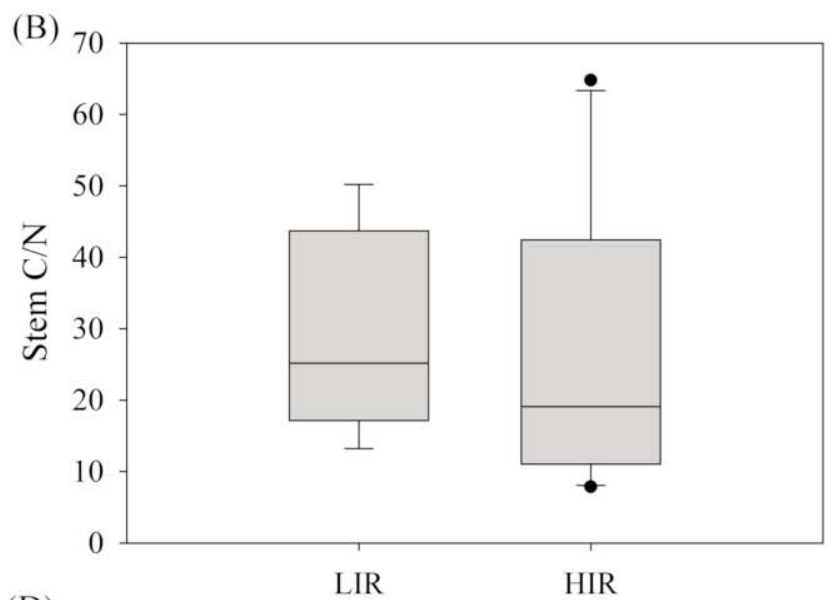

(D)

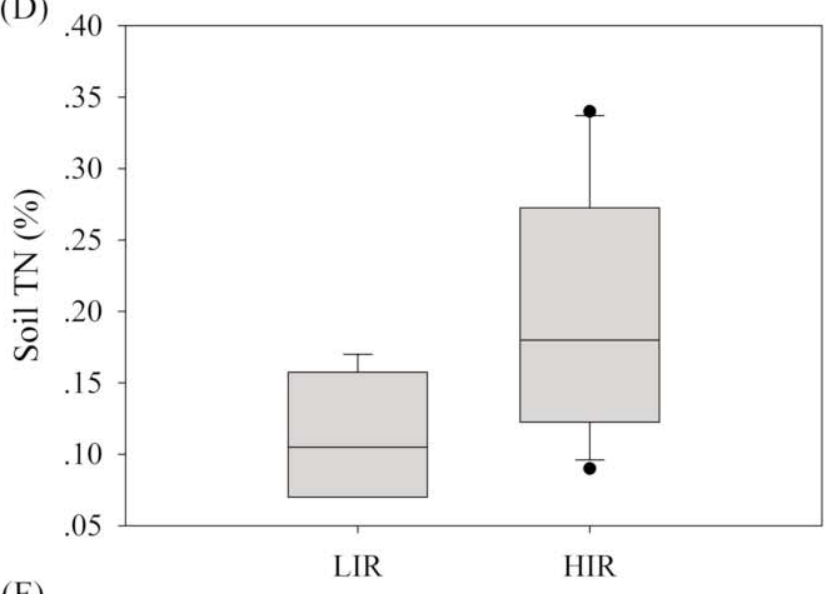

F)

Fig. 3. Carbon-to-nitrogen (C/N) ratio in (A) root, (B) stem, and (C) leaf of Alternanthera philoxeroides samples; (D) soil total nitrogen $(\mathrm{TN}),(\mathrm{E})$ soil $\mathrm{pH}$, and (F) soil moisture in rivers that were lightly invaded (LIR) and heavily invaded (HIR) by the weed, with median, $25 \%, 75 \%$, and range for soil properties data. 
Table 3. Analysis of variance (ANOVA) of soil properties of 21 paired spots in the five studied rivers. ${ }^{1}$

\begin{tabular}{|l|c|c|c|c|c|c|c|c|}
\hline & Cai River & Laoyun River & Shizi River & Si River & Xinxue River & df & F value & p value \\
\hline Plant root C/N & $42.36 \pm 12.10^{\mathrm{a}}$ & $16.36 \pm 29.63^{\mathrm{b}}$ & $19.00 \pm 5.09^{\mathrm{b}}$ & $32.26 \pm 15.73^{\mathrm{ab}}$ & $16.16 \pm 1.82^{\mathrm{b}}$ & 4.19 & 5.588 & 0.006 \\
\hline Soil TN & $0.07 \pm 0.02^{\mathrm{a}}$ & $0.19 \pm 0.08^{\mathrm{bd}}$ & $0.15 \pm 0.05^{\mathrm{bc}}$ & $0.13 \pm 0.03^{\mathrm{ab}}$ & $0.21 \pm 0.07^{\mathrm{d}}$ & 4.41 & 8.250 & 0.000 \\
\hline Soil TC & $1.43 \pm 0.61^{\mathrm{a}}$ & $1.55 \pm 1.10^{\mathrm{a}}$ & $3.26 \pm 1.56^{\mathrm{b}}$ & $1.70 \pm 0.46^{\mathrm{a}}$ & $3.30 \pm 1.59^{\mathrm{b}}$ & 4.41 & 5.588 & 0.001 \\
\hline Soil C/N & $20.00 \pm 8.64^{\mathrm{cd}}$ & $7.11 \pm 3.00^{\mathrm{a}}$ & $21.38 \pm 4.73^{\mathrm{d}}$ & $13.54 \pm 1.79^{\mathrm{b}}$ & $15.85 \pm 3.74^{\mathrm{bc}}$ & 4.41 & 9.410 & 0.000 \\
\hline Soil pH & $8.13 \pm 0.06^{\mathrm{a}}$ & $7.81 \pm 0.35^{\mathrm{b}}$ & $7.83 \pm 0.05^{\mathrm{b}}$ & $7.88 \pm 0.20^{\mathrm{b}}$ & $7.80 \pm 0.09^{\mathrm{b}}$ & 4.41 & 5.267 & 0.002 \\
\hline SOC & $0.42 \pm 0.12^{\mathrm{a}}$ & $1.31 \pm 0.91^{\mathrm{b}}$ & $1.54 \pm 0.70^{\mathrm{bc}}$ & $0.86 \pm 0.38^{\mathrm{ab}}$ & $2.22 \pm 1.23^{\mathrm{c}}$ & 4.41 & 6.892 & 0.000 \\
\hline Soil moisture & $0.38 \pm 0.09^{\mathrm{a}}$ & $0.55 \pm 0.46^{\mathrm{ab}}$ & $1.06 \pm 0.39^{\mathrm{c}}$ & $0.49 \pm 0.23^{\mathrm{a}}$ & $0.89 \pm 0.50^{\mathrm{bc}}$ & 4.41 & 5.107 & 0.002 \\
\hline
\end{tabular}

${ }^{1}$ No Alternanthera philoxeroides was found in Zhuzhaoxin River, so it was eliminated from further analysis.

$\mathrm{C} / \mathrm{N}$ - carbon-to-nitrogen ratio; TN - total nitrogen; TC - total carbon; SOC - soil organic carbon

Different lowercase letters indicate significant differences among the five rivers (Duncan's test).

to stem or leaf $\mathrm{C} / \mathrm{N}$, so coverage was closely associated with soil properties. Therefore, we concluded that root $\mathrm{C} / \mathrm{N}$ was an important factor that affected the invasion of A. philoxeroides. Vegetative propagation (with storage roots and stems) is the primary regeneration strategy in the field [34]. Root heterogeneity and root length were related to invasion in native grasslands in North America [35]. Allocation of energy to storage roots also plays an important role in the life history of $A$. philoxeroides [31]. The large root reserves act as the primary energy source for shoot emergence in early spring and also enable rapid shoot regrowth after physical damage. Root fragments can act as propagules for long-distance dispersal by flooding or human activities (e.g. soil transportation, dredging). Therefore, allocation of energy to storage roots is a measure of reproductive allocation for $A$. philoxeroides [26, 36].

The $\mathrm{C} / \mathrm{N}$ ratio is an important predictor of the rate of mineralisation for a given type of organic matter and is also a determining factor in plant biomass, which has a decisive influence on invasion. The processes of mineralisation and immobilisation constantly occur simultaneously. When the $\mathrm{C} / \mathrm{N}$ ratio of decomposing organic residues is between 20:1 and 30:1, mineralisation and immobilisation occur at fairly equal rates [37]. The $\mathrm{C} / \mathrm{N}$ ratio of $A$. philoxeroides is around $24: 1$, indicating that a good balance of mineralisation and immobilisation exists.

Invasive species with lower $\mathrm{C} / \mathrm{N}$ ratios are associated with more synergistic $\mathrm{N}$ loss over time [38]. It has been suggested that invasive species may further synchronise the release of $\mathrm{N}$ from the litter layer with plant $\mathrm{N}$ demand, enhancing positive feedback to invasion. As plants interact with their environments, environmental factors can influence plant invasion and plant invasions can influence the environment. Invaders can alter important ecosystem properties, such as native species richness, nutrient pools, transformations, and even bacterial community composition, depending on the time since invasion [39]. Successful plant invaders can have legacies that affect the soil-microbial associations of native plants, and these effects can inhibit the growth of native plant species in invaded communities [15].
The Cambara invasion has fundamentally increased the $\mathrm{C}$ and nutrient storage of Pantanal soils [40], and the Spartina alterniflora invasion has increased SOC and TN concentrations [41, 42]. However, the impact of plant invasions on soil organic carbon dynamic is not well understood.

To answer the second question we proposed, significant differences in soil properties were not apparent at a small scale (plot scale); however, there were significant differences at the larger scale (river scale). Abiotic processes such as stream flow are often more homogenous at smaller spatial scales, so biotic processes are thought to be better predictors of invasion success at small scales [19]. High A. philoxeroides cover was associated with low native cover [43]. Our results showed that at small scales, especially in the riparian zone, abiotic processes like topographic factors may strongly influence the invasion success of $A$. philoxeroides. Topographic factors including landform, slope, and distance to water were important factors regulating species and community distribution in riparian zones [44].

Flow accumulation, slope, annual average temperature, and annual precipitation dramatically influence weed distribution [14]. A field survey in southeast China found that A. philoxeroides dominate microhabitats (e.g. wet abandoned fields, swamps, marsh dunes, gravel dunes) that have high levels of soil nutrients and water availability [45]. As the water flows, the soil in the river bottom slowly flows as well, which increases its homogeneity. A. philoxeroides was rarely distributed in wide rivers that had rapid water velocity. However, in certain sites in the riparian zone with flatter terrain, water flows slowly and the environment is more suitable for $A$. philoxeroides. The river dynamics not only affect colonisation but also cause local extinctions, so plant populations become spatially subdivided and their persistence becomes dependent on the spatial dynamics in the network of local populations.

Dispersal characteristics and propagule bank persistence are main determinants of colonising ability and local extinction rate, which in turn are important determinants of invasive species' regional meta-population viability [26]. 
It is difficult to include all the sophisticated variables necessary to accurately predict plant invasion success at a smaller scale, such as native species, hydrological processes, soil properties, and microbes. Therefore, research on the factors influencing the distribution of invasive plants should be conducted at suitable scales depending on the study factors.

In conclusion, $A$. philoxeroides coverage was correlated with river nutrient properties; rivers with higher SOC and soil TN showed higher A. philoxeroides coverage at the river scale. Soil $\mathrm{pH}$ was negatively correlated with weed coverage, SOC and soil TN. However, there was no significant difference in the soil properties of paired plots, suggesting that soil properties mainly affect the distribution of A. philoxeroides at the river scale. Efforts to prevent A. philoxeroides invasion should focus on rivers with higher SOC and soil TN and lower soil $\mathrm{pH}$.

\section{Acknowledgements}

We thank Da Yin and Fanbao Hu for helping collect soil and plant samples, and Wentao Wang for drawing sample maps. This study was financially supported by the National Natural Science Foundation of China (Nos. 31200426 and 31400356), the National Water Special Project (No. 2012ZX07203-004), and the Fundamental Research Funds of Shandong University (No. 2015JC023). The authors also thank the Editage Company for improving the quality of English used in the manuscript.

\section{References}

1. ALLISON K. Ecosystems and human well-being: health synthesis. J. R. Soc. Promo Health. 126, (4), 192, 2006.

2. PYŠEK P., RICHARDSON D.M. Invasive Species, Environmental Change and Management, and Health. Annu. Rev. Env. Resour. 35, (1), 25, 2010.

3. POWELL K.I., CHASE J.M., KNIGHT T.M. A Synthesis of Plant Invasion Effects on Biodiversity across Spatial Scales. Am. J. Bot. 98, (3), 539, 2011.

4. LE MAITRE D.C. Predicting invasive species impacts on hydrological processes: The consequences of plant physiology for landscape processes. Weed Technol. 18, 1408, 2004.

5. EHRENFELD J.G. Effects of exotic plant invasions on soil nutrient cycling processes. Ecosystems. 6, (6), 503, 2003.

6. EHRENFELD J.G. Ecosystem Consequences of Biological Invasions. Annu. Rev. Ecol. Evol. S. 41, 59, 2010.

7. LEVINE J.M., VILA M., D'ANTONIO C.M., DUKES J. S., GRIGULIS K., LAVOREL S. Mechanisms underlying the impacts of exotic plant invasions. P. Roy. Soc. B-Biol. Sci. 270, (1517), 775, 2003.

8. LIAO C., LUO Y., JIANG L., ZHOU X., WU X., FANG C. CHEN J.K., LI B. Invasion of Spartina alterniflora enhanced ecosystem carbon and nitrogen stocks in the Yangtze Estuary, China. Ecosystems. 10, 1351, 2007.

9. LIU J., CHEN H., KOWARIK I., ZHANG Y.R., WANG R.Q. Plant invasions in China: an emerging hot topic in invasion science. NeoBiota. 15, 27, 2012.
10. PYŠEK P., JAROSIK V., PERGL J., RANDALL R., CHYTRY M., KUHN I., TICHY L., DANIHELKA J., CHRTEK J.J., SADLO J. The global invasion success of Central European plants is related to distribution characteristics in their native range and species traits. Divers. Distrib. 15, 891, 2009.

11. ALPERTA P., BONE E., HOLZAPFEL C. Invasiveness, invasibility and the role of environmental stress in the spread of non-native plants. Perspect. Plant Ecol. 3, 52, 2000.

12. DONG B.C., YU G.L., GUO W., ZHANG M.X., DONG M., YU F.H. How internode length, position and presence of leaves affect survival and growth of Alternanthera philoxeroides after fragmentation? Evol. Ecol. 24, 1447, 2010.

13. BASSETT I., PAYNTER Q., BEGGS J.R. Invasive Alternanthera philoxeroides (alligator weed) associated with increased fungivore dominance in Coleoptera on decomposing leaf litter. Biol. Invasions. 13, 1377, 2010.

14. CHEN L.L., YU Y., HE X.J. Historical invasion and expansion process of Alternanthera philoxeroides and its potential spread in China. Biodivers. Sci. 16, (6), 578, 2008 [In Chinese].

15. JORDON N.R., ALDRICH-WOLFE L., HUERD S.C., LARSON D.L., MUEHLBAUER G. Soil-occupancy effects of invasive and native grassland plant species on composition and diversity of mycorrhizal associations. Invas. Plant Sci. Mana. 5, (4), 494, 2012.

16. LAZZARO L., GIULIANI C., FABIANI A., AGNELLI A.E., PASTORELLI R., LAGOMARSINO A., BENESPERI R., CALAMASSI R., FOGGI B. Soil and plant changing after invasion: The case of Acacia dealbata in a Mediterranean ecosystem. Sci. Total Environ. 497, 491, 2014.

17. WU X.W., LUO J., CHEN J.K., LI B. Spatial patterns of invasive alien plants in China and its relationship with environmental and anthroplogical factors. J. Plant Ecol. 30, 576, 2006.

18. PINTOR L.M., SIH A. Scale dependent effects of native prey diversity, prey biomass and natural disturbance on the invasion success of an exotic predator. Biol. Invasions. 13, (6), 1357, 2010.

19. FRIDLEY J.D., STACHOWICZ J.J., NAEEM S., SAX D. F., SEABLOOM E. W., SMITH M. D., STOHLGREN T. J., TILMAN D., VON HOLLE B. The invasion paradox: reconciling pattern and process in species invasions. Ecology. 88, (1), 3, 2007.

20. FLEMING J.P., DIBBLE E.D. Ecological mechanisms of invasion success in aquatic macrophytes. Hydrobiologia. 746, 23, 2014.

21. WU S.H., SUN H.T., TENG Y.C., REJMÁNEK M., CHAW S.M., YANG T-Y.A., HSIEH C.F. Patterns of plant invasions in China: Taxonomic, biogeographic, climatic approaches and anthropogenic effects. Biol. Invasions. 12, (7), 2179, 2010.

22. EPA. Functions and values of wetlands. Environmental Protection Agency, United States, Office of Water, Office of Wetlants, Oceans and Watersheds (4502T). EPA 843-F-01002c. September 2001.

23. MATTINGLY W.B., REYNOLDS H.L. Soil fertility alters the nature of plant-resource interactions in invaded grassland communities. Biol. Invasions. 16, 2465, 2014.

24. NILSSON C., BROWN R.L., JANSSON R., MERRITT D.M. The role of hydrochory in structuring riparian and wetland vegetation. Biol. Rev. Camb. Philos. Soc. 85, (4), 837, 2010. 
25. RIIS T., SAND-JENSEN K. Dispersal of plant fragments in small streams. Freshwater Biol. 51, (2), 274, 2006.

26. PAN X.Y., GENG Y.P., SOSA A., ZHANG W.J., LI B., CHEN J.K. Invasive Alternanthera philoxeroides: biology, ecology and management. Acta Phytotaxon. Sin. 45, (6), 884, 2007 [In Chinese].

27. BROOKS M.L. Effects of Increased Soil Nitrogen on the Dominance of Alien Annual Plants in the Mojave Desert. J. Applied Ecol. 40, 344, 2003.

28. TRUSCOTT A.M., PALMER S.C., SOULSBY C., WESTAWAY S., HULME P.E. Consequences of invasion by the alien plant Mimulus guttatus on the species composition and soil properties of riparian plant communities in Scotland. Perspect. Plant Ecol. 10, 231, 2008.

29. CASTRO-DIEZ P., GODOY O., ALONSO A., GALLARDO A., SALDANA A. What explains variation in the impacts of exotic plant invasions on the nitrogen cycle? A meta-analysis. Ecol. Lett. 17, 1, 2014.

30. JULIEN M.H., SKARRATT B., MAYWALD G.F. Potential geographical distribution of alligator weed and its biological control by Agasicles hygrophila. J. Aquat. Plant Manage. 33, 55, 1995.

31. JIA X., PAN X.Y., LI B., CHEN J.K., YANG X.Z. Allometric growth, disturbance regime, and dilemmas of controlling invasive plants: a model analysis. Biol. Invasions. 11, (3), 743, 2008.

32. LU R.K. Analysis Method of Soil and Agricultural Chemistry. China Agricultural Science and Technology Press, Beijing. 2000 [In Chinese].

33. SHAO X.X., YANG W.Y.,WU M., JIANG K.Y. Soil organic carbon content and its distribution pattern in Hangzhou Bay coastal wetlands. Chinese J. Appl. Ecol. 22, (3), 658, 2011 [In Chinese].

34. SOSA A.J., JULIEN M.H., CORDO H.A. New research on Alternanthera philoxeroides (alligator weed) in its South American native range. Proceedings of the XI International Symposium on Biological Control of Weeds, CSIRO Entomology, Canberra. pp. 180-85, 2004.

35. VANESS B.M., WILSON S.D., MACDOUGALL A.S. Decreased root heterogeneity and increased root length following grassland invasion. Func. Ecol. 28, (5), 1266, 2014.
36. JIA X., PAN X.Y., SOSA A., LI B., CHEN J.K. Differentiation in growth and biomass allocation among three native Alternanthera philoxeroides varieties from Argentina. Plant Spec. Biol. 25, (2), 85, 2010.

37. PAUL E.A. Soil Microbiology, Ecology, and Biochemistry Fourth edition, Academic Press. 2015.

38. SCHUSTER M.J., DUKES J.S. Non-additive effects of invasive tree litter shift seasonal $\mathrm{N}$ release: a potential invasion feedback. Oikos. 123, (9), 1101, 2014.

39. GEDDES P., GRANCHAROVA T., KELLY J.J., TREERING D., TUCHMAN N.C. Effects of invasive Typha $\times$ glau$c a$ on wetland nutrient pools, denitrification, and bacterial communities are influenced by time since invasion. Aquat. Ecol. 48, (3), 247, 2014.

40. VOURLITIS G.L., LOBO F.D., BIUDES M.S., ORTIZ C.E.R., NOGUEIRA J.D. Spatial Variations in Soil Chemistry and Organic Matter Content across a Vochysia divergens Invasion Front in the Brazilian Pantanal. Soil Sci. Soc. Am. J. 75, (4), 1554, 2011.

41. LIU J.E., ZHOU H.X., QIN P., ZHOU J. Effects of Spartina alterniflora salt marshes on organic carbon acquisition in intertidal zones of Jiangsu Province, China. Ecol. Eng. 30, (3), 240, 2007.

42. CHENG X., LUO Y., CHEN J., LIN G.H., CHEN J.K., LI B. Short-term C4 plant Spartina alterniflora invasions change the soil carbon in $\mathrm{C} 3$ plant-dominated tidal wetlands on a growing estuarine island. Soil Biol. Biochem. 38, (12), 3380, 2006.

43. BASSETT I., PAYNTER Q., HANKIN R., BEGGS J.R. Characterising alligator weed (Alternanthera philoxeroides; Amaranthaceae) invasion at a northern New Zealand lake. New Zeal. J. Ecol. 36, (2), 216, 2012.

44. LIU W.Z., LIU G.H., ZHANG Q.F. Shoreline vegetation in the Danjiangkou Reservoir: characteristics, related factors, and differences with adjacent riverine wetlands. Clean Soil Air Water. 42, (7), 1014, 2014.

45. PAN X.Y., GENG Y.P., ZHANG W.J., LI B., CHEN J.K. The influence of abiotic stress and phenotypic plasticity on the distribution of invasive Alternanthera philoxeroides along a riparian zone. Acta Oecol. 30, (3), 333, 2006. 